\title{
From Surface to Deep Learning Approach: An EFL Teaching Real-life Experience
}

\author{
Messaouda LITIEM \\ PhD Student of English at Algiers 2 University, Algeria
}

\begin{abstract}
This study is one of my real-life experiences as an EFL teacher who worked on the idea of changing students' approach of learning from being surface to making it deep and effective. Its purpose was to reach with students the best of their learning in a world which encourages laziness and superficial ways of getting knowledge. The population of the study were EFL pupils in El Bashir El Ibrahimi secondary school and EFL learners in a private school in Touggourt, Algeria. The two samples were interviewed and their oral and written performances were evaluated after a semester of study. During this semester, participants from both samples were placed in an environment which supports deep learning. The role of the teacher in this teaching journey was to create all the conditions which contribute to promote deep approach of learning. After the analysis of the data collected and the results obtained, the researcher arrived to prove that applying deep learning principles improves students' performance. Moreover, the change in the students' learning approach is an impact of teacher intervention. Bringing this type of real-life teacher experiences into light and discussing them can be of great help to many teachers all over the world.
\end{abstract}

Keywords: approach change, EFL learner, EFL pupil, private school, secondary school

\section{Introduction}

In today's world, which is marked by easier ways of living and new technologies, many people believe that everything can be reached with less effort. However, this is not the case in teaching and learning. Thanks to globalization, students can reach plenty of information anytime and everywhere; consequently, they may spend little efforts on seeking knowledge, which results in adapting a superficial approach to learning. This type of learning can have undesirable effects on students' aptitude for learning, motivation, comprehension, production, scoring, and their future orientations. Therefore, it is the role of the teacher to work on changing this surface learning into deep one to improve the current learning features.

In many studies, deep learning is always associated with good outcomes; this is why it is the learning approach that teachers prefer their students to adopt. Although there are many reasons why students choose certain learning approach, in this study we confined the results to one external factor who is the teacher. The teacher as a principal factor can monitor most of the other factors behind approach choice by students, whether internal or external. S/he can sort out what is causing his/ her students to be surface learners and thereby propose solutions and take actions which may eventually help students to deepen their learning method. 


\section{and Education}

In this regard, I would like to share with you two cases I experienced with surface and deep approaches of learning: one with my students of English as a foreign language in secondary school and the other with adults who were interested in learning English for personal reasons in a private school in Algeria. First, I will start with describing my experience of a learning approach from the perspective of being a former student. Then, I will introduce the two concepts surface and deep learning; their background, definitions, and characteristics, followed by research method, results, and discussion.

\section{Personal Experience of a Learning Approach}

In 2007 when I was a pupil in secondary school, I had difficulties to perform in Physics, yet that was not typical at all for those who were enrolled in scientific streams. At that time, I had many reasons to expect that my below desired performance was going to impact my success in the Baccalaureate Exam, and definitely the rest of my life. I was quite certain of my expectations because I had no natural talents in Physics, was bad at complex calculations, and felt lack of intelligence and frustration in front of my teacher and towards tasks. I did have the opportunity to improve my level, but I did not know how. I used to memorize rules and formulas for the day of the exam, adopting a surface strategy of learning in scientific terms. Fortunately, I passed my BAC Exam having six in Physics and ten out of twenty as a general average; what means I could probably fail if I did not rely heavily on the other subjects, which was the case of most of my colleagues in class at that time.

Contrary to what my teacher of Physics could not do, my teacher of Biology behaved in a different way. He used to care a lot about passive students and adopted some strategies which engage all the class during the lesson. His strategies helped a lot in making students and me in particular in adopting a very deep approach of learning Biology. Our averages in the end proved that the majority of students achieved success in the subject despite its difficulty.

A couple of years later after a long journey of being a student and a teacher and becoming a PhD student, I figured out that it was not the right way to study Physics and achieve success. I arrived to realize that my teacher of Physics could have a lot to do to help me deepen my way of learning and probably get my BAC with distinction. If he tried to work on the idea of changing my approach of learning, the outcomes would likely be different. My dissatisfying experience of learning Physics inspired me in some way later in my life as a teacher. Such inspiration is brought to the core of this article.

\section{Surface and Deep Approach of Learning}

What do surface and deep learning mean? Surface and deep learning is not something that researchers came up with, rather they are strategies which students exhibit to approach their learning. The two terms were first used by the two scholars Marton and Säljo (1976) (Floyd, Harrington \& Santiago, 2009: 183), who differentiated between two types of ways learners use to approach academic tasks; one focuses on rote learning and memorization and the second extends to more than these efforts. The former came to be called surface approach, whereas the latter was named deep approach to learning. After Marton and Säljo, many researchers made their research on the two learning approaches namely: Diseth (2002), Diseth (2003), Diseth, Pallesen, Hovland, \& Larsen (2006), Furnham, Monsen, \& Ahmetoglu (2009), Diseth, Pallesen, Brunborg, \& Larsen (2010). These studies focused on the positive effects of 


\section{and Education}

deep learning on participants' achievement and learning outcomes. In this regard, Prosser \& Trigwell state: "deep approaches to learning are more likely to be associated with higher quality learning outcomes." (1999: 4).

According to Hamm and Robertson (2010: 953), the two learning approaches differ in a number of characteristics which are: time and effort, questions asked by learners, level of research, impact of assess-ability, cognitive effort, and importance of personal interest. First, learners who adopt a surface approach tend to spend short amount of time and effort in doing a task when compared to deep approach holders. Second, they generally seek the manner to fulfill a task asking the question 'how'. Unlike surface learners, those who follow a deep approach of learning look for the objectives of doing a task asking the question 'why';i.e, they try to find out the deep meaning of doing a certain activity rather than another. Third, they both differ in their level of searching. While surface learning stops at the limits of the information provided, deep learning goes beyond the task and the classroom walls to expand knowledge. The fourth feature of the two approaches of learning is the impact of assessability. Surface learners focus on the assessable tasks only; however, deep learners focus on all the tasks whether assessed or not. In addition, they are mostly successful in recalling information, whereas deep learners show a good commend of higher-order thinking skills and capacities like discussion, problem-based questions, etc. They also differ in their cognitive efforts. Those who adopt a surface approach rely on rote learning and memorization; conversely, deep ones try to develop a deeper understanding of the task. The last point of difference lies in the importance of personal interest. Deep approach followers are internally motivated to learn. This is why they engage quickly and show instances of active prior knowledge or familiarity with the task; the fact that increases their desire and curiosity to understand every single point of information. On the contrary, learners who are surface are instrumentally motivated by exams, marks, rewards, etc. This is why they are not passionate about what they learn; what makes them passive in constructing both prior and expected-tolearn knowledge. Besides, they treat the task as unrelated patterns of information concentrating just on areas of personal interest not like deep learners who do not look at the task as separate elements, yet they see the whole elements and their relationships. Sections 3 and 4 in this article reflect these characteristics in concrete examples.

\section{Method}

The study took place in the city of Touggourt in Algeria during the academic year 2014/2015. It was carried out during the first semester of the year. The method used was qualitative since it was the suitable method for the purpose of the study, the type of the data needed, and the population under investigation. The participants of the study included twelve EFL secondary school pupils and five adults in a private school in two institutions: El Bashir El Ibrahim secondary school and Fethallah Private School. Data for investigation were collected through using an interview and an experiment through which deep approach characteristics were maintained. The two interviews consisted of open-ended questions that were intended to elicit information from the participants about the issue of this research. While the first sample received a different way of teaching than their secondary school colleagues, the second sample was trained using an innovative program designed depending on their needs. What follows is a description of the samples, the research tools, and the procedures followed in carrying out the study. 


\section{and Education}

The first sample included third year secondary school pupils who were enrolled in civil engineering stream; which means subjects like History, Philosophy, and Languages were of a secondary importance to them. Their exact number was twelve. They had a low record of ratings in English and less interest in the lessons presented. They reflected all the characteristics of surface learners. What I noticed in those students was that most of them used to spend less time and effort in doing tasks, always looked for model answers before they even try, were contented with the information provided by the teacher without further searching, used to care about scores rather than areas of improvement, seemed less intelligent when it came to higher-order-thinking activities, used to come to classroom empty-minded and unable to grasp all the points dealt with during the lesson. Consequently, they looked passive, demotivated, rarely engaged, less interested, and low achievers.

The second sample of students was in private school with adults who were interested in learning English for own reasons. I had students who were intrinsically motivated to learn, but they did not know how. All what they did was memorization of English vocabulary, which looked very surface. As I always used to do at the beginning of any teaching journey, interview was desired to diagnose the learning situation and identify students' needs. Each time I had new registrations I held interviews with them through which I wanted to know the reasons behind their decisions to learn English, their academic level, whether they had already participated in English training programs, their perceptions and conceptions of learning English, and the constraints they faced when they tried to learn. After each interview, I used to determine students' level at English according to the CEFR (Common European Framework of Reference for languages learning). I had a variety of students; engineers in the field of oil and gas, engineers in mechanics, electricity, geology, architecture and aircraft, teachers, secondary school pupils, PhD students of other subjects, specialists in agriculture and nutrition, administrators, lawyers, doctors, and many others. From the participants' responses, I realized that they believed in having language talent to be able to learn it, they considered themselves too old to learn a second language, thought they could not learn a language if they could not travel to the country where it is used as a native tongue, could not retrieve all the vocabulary they learnt at the moment of speaking, felt frustrated when talked to native speakers, perceived learning a language to a native like proficiency, and most of them had a previous failing learning experience in other private schools.

\section{Results and Discussion}

With the first sample, I decided to reconsider my way of teaching focusing on factors affecting approach choice among my pupils, such as motivation, students' perceptions, conceptions and awareness of learning and course value, and effective methods of assessment. First, I focused on motivation. In the same path, Prosser and Trigwell claim that students who adopt a surface learning approach are not intrinsically motivated (1999: 3). In order to check this out in my students, the question asked in the interview conducted with them on what motivated them to learn English shows that the majority were externally motivated towards the English class as they saw it a space where they got rid of the pressure of other principal subjects like Maths and Physics. They stated that they needed to spend more time and efforts on the latters, and secondary subjects like English received less importance from their part since they had little impact on the general average they were supposed to get. What I found out from the analysis of the interview responses was that my students did not see the relationship between English and the other essential subjects, thus I used multiple incentives 


\section{and Education}

to motivate them to learn English. I started with making them aware of the role of English in their next stage of study at university as they will be supposed to be able to analyze sources on science written in English. I insisted saying: "you are not going to study the science of Arabs only!". Then, I tried to find out whether the syllabus of English shares some points with the syllabus of other scientific subjects and I brought out one related to Physics which was astronomy and the solar system. I went to my sister who was a teacher of Physics and asked her about the main themes students were expected to learn in Physics in relation to astronomy. Based on these, I designed my own lessons of English with texts different from those in the textbook but keeping the same intended objectives. It was that way my students felt very motivated to learn something they had already an idea about. Furthermore, they came to realize the relation between English and Physics as a case here. I also used rewarding. Each time a student made a little meaningful effort, I gave him/ her booklets of Maths or Physics written in English. That was another way to illustrate the relationship between English and the other subjects. The second factor I focused on was students' perceptions, conceptions and awareness of learning and course value. It is said that the learning approach students adopt is linked to the latters (Prosser \& Trigwell, 1999: 4). As a teacher who believes that adopting a surface approach is not static and students can shift from one approach to the other depending on the environment where learning takes place, I tried to maintain an appropriate context of learning to help my students shift from surface to deep learning. As far as course value is related, there was a study carried out by Floyd, Harrington and Santiago (2009) in which they argued that there is a relationship between students' perceptions of course value, their engagement, and deep learning. The first two variables impact the approach students adopt to learning. It is claimed that if students' perceptions are positive, they engage and learn better. Therefore, I focused on course design and activities used. I used to adjust and simplify the courses according to my students' needs and level of understanding so that to eliminate any negative perception of learning English that might affect their conceptions and engagement. I also used to teach them some self-regulation strategies which could increase deep learning and lead to positive outcomes such as setting a goal, taking notes, managing time, seeking assistance from either the teacher or peers to ask for help, clarifications or examples, preparation and revision strategies, etc. My relationship with my students, the type of instruction offered the manner in which the instruction was given were other sub factors to consider in my classroom. I remember providing care to my students and most of the time they felt supported. Another practice I used to do was scaffolding techniques. I used to paraphrase, think aloud, slow down the rate of my speech delivery, pause when necessary, enhance group work to think, pair, and share in order to give my students opportunities for interaction and discussion, employ ICTs, etc. The third factor affecting my students' choice of their learning approach was assessment. In a study carried out by Donninson and PennEdwards (2012), it was proved that assessment influences the learning approach students adopt. My method of assessment was characterized by differentiating activities, implementing them in order of simplicity and complexity, modeling so as to break any kind of barriers students might face, and providing multiple continuous feedback. All the efforts I made were reflected in some of my students who showed a radical change in their way of learning and consequently their learning outcomes.

The program I developed for the second group was of two sections: I named the first 'Arts and Skills of Communication in English' and the second 'I can Speak English'. The first section included fifteen lessons learnt during two months with an average of three sessions of two hours long per week, while the second section was full practice-based sessions held every 


\section{and Education}

day during a closed week that was open to be continuous depending on students' needs and request. Lessons included in the first section of the program were: break the ice for language learning, master pronouns, pronounce right, learn how to ask questions, listen and practice, make conversations, discover sound change in spoken English, never pretend that you understand, understand meaning confusion with homophones and homonyms, acquire the techniques to avoid Arabic, write your CV, speak up your CV to job interviewers, learn how to write a letter of application, and improve your skills of presentation in English, whereas practices included in the second section were like: speak fast, picture brainstorming, sit an interview, , acting, going for a trip outside the classroom walls to meet some friends speaking English so as to reduce shyness and build self-confidence, the ball game, reporting news, story-telling, and free topics discussion. The principles I relied on during this English training were convincing my students that there were no language genes to make excuses not to learn languages, no age limits, no need to travel to foreign countries in the nowadays developed technology which made it possible to contact the whole world simply by a click on a chat icon for instance to connect with native speakers across the Planet, the invalidity of memorizing isolated lists of words, rather using phrases which sound more meaningful and context dependent, and last I worked on my students' psychological aspect to eradicate their barriers in learning and using English keeping saying that 'nobody can learn and use a language alone 'أنجلش_ ها End in isolation'. In addition to this, I created a Facebook page named 'English through which I used to follow my students' progress outside the classroom walls with more vivid posts and activities enhanced with different kinds of incentives and rewards. English_ha reached two-thousand followers in a very short time. After a short period of time from implementing the so called program, I was about to confirm its success for the coming reasons. First, participants' registrations increased quickly. Second, the ones who had already benefited from the training expressed their full satisfaction of the level they reached. Third, they asked for more closed weeks feeling they would reach the best of their learning that way. Fourth, my followers on English_ha asked for an on line English training based on such program, especially for those who lived far from my city. I can affirm that the program I created would never succeed without the implementation of deep learning approach with my students. I served in increasing their motivation and raising their interest in learning English, made them excited to spend more time and effort on learning, and led them to be curious to make further research on how to develop their abilities in using English.

\section{Conclusion}

Throughout this article, I presented a real-life experience on surface and deep learning approaches: one with my pupils in secondary school and the other in private school. The findings of the study reported in this paper support the prior studies which explored the positive effects of deep learning approach on students' learning and academic achievement. It also implies that the change in student approach of learning can be reached out by the teacher as an external factor controlling any other existing factors.

As any researcher, I confronted some obstacles while working on this subject which had probably influenced this research and made its findings limited. First, the time factor was a big problem. Carrying out a research on approaches of learning cannot be fulfilled in six

months. Second, pupils of the first sample were supposed to pass their Baccalaureate Exam which made it impossible to take them for another semester and make them focused. Third, they were to cover a predetermined official syllabus to be tested on. Despite these difficulties, 


\section{and Education}

I made great efforts to make this work successful. I hope that the results of this study will contribute in enhancing teachers' practices and improving students' learning in EFL classrooms.

Scientifically speaking, there are some limitations addressed to this study because what I have proposed is based on just small samples and cannot be generalized to other cases. In order to make the results generalizable, further similar studies have to be done with larger samples in different regions taking longer periods of time. Unless this is done, I still question the generalizability of the given findings, yet I do believe that a little work is important for continued efforts in this field.

After this humble experience, I had the conviction of believing in my students' capacities and training them to be better than me. Now, I have the will to continue this journey with my students at university in the near future. In this regard, Prosser and Trigwell stated: "... university teachers who focus on their students and their students' learning tend to have students who focus on meaning and understanding, while university teachers who focus on themselves and what they are doing tend to have students who focus on reproduction." (1999: 142). That is to say, all of the good learning is student centered. Consequently, it is important to focus on students' approaches to learning so that a teacher can bring out all the capacities in them to reach the best of their learning. To conclude, a teacher needs to realize that teaching is not just transmission and learning is not just acquisition. There is much to care about in between.

\section{Acknowledgment}

This work is an output of the collaboration of the EFL pupils in El Bashir El Ibrahimi secondary school and the EFL learners in Fethallah private school in addition to the facilities offered by the staff of the two schools. I am also grateful to the two inspectors of EFL teaching in Touggourt district, Mr Mourad Abadli and Mr Youcef Siagh, for their intense kindness and insistent support.

\section{References}

[1] Donninson, S. \& Penn-Edwards, S. (2012). Focusing on First Year Assessment: Surface or Deep Approaches to Learning? The International Journal of the First Year in Higher Education, 3(2). 9-20. Doi: 10-5204/intjfyhe. V3i2.127

[2] Floyd, K. S., Harrington, S. J. \& Santaigo, J. (2009). The Effect of Engagement and Perceived Course Value on Deep and Surface Learning Strategies. Informing Science: The International Journal of an Emerging Transdiscipline, Volume 12

[3] Hamm, S. \& Robertson, I. (2010). Preferences for deep surface learning: A Vocational education case study using a multimedia assessment activity. Australian Journal of Educational Technology, 28(7). 951-965

[4] Prosser, M. and Trigwell, K., (1999). Understanding Learning and Teaching: The Experience in Higher Education. The Society for Research into Higher Education (SRHE) and Open University Press, Buckingham, Celtic Court, 22 Ballmoor.

[5] Diseth, A. (2002). The relationship between Intelligence, Approaches to Learning and Academic Achievement. Scandinavian Journal of Educational Research, 46, 219-230. 


\section{3rd International Conference on Advanced Research in Teaching and Education}

[6] Diseth, A. (2003). Personality and Approaches to Learning as Predictors of Academic Achievement. European Journal of Personality, 17, 143-155.

[7] Diseth, A., Pallesen, S., Hovland, A., \& Larsen, S. (2006). Course experience, approaches to learning and academic achievement. Education Training, 48(2/3), 156-169.

[8] Diseth, A., Pallesen, S., Brunborg, G. S., \& Larsen, S. (2010). Academic Achievement among First Semester Undergraduate Psychology Students: The Role of Course Experience, Effort, Motives and Learning Strategies. Higher Education, 59, 335-352.

[9] Furnham, A. , Monsen, J., \& Ahmetoglu, G. (2009). Typical Intellectual Engagement, Big Five Personality Traits, Approaches to Learning and Cognitive Ability Predictors of Academic Performance. British Journal of Educational Psychology, 79, 769-782. 